\title{
STUDI PEMBUATAN BROWNIES KUKUS DENGAN SUBSTITUSI TEPUNG DAUN SINGKONG (MANNIHOT UTILISSIMA)
}

\section{(The Making Of Brownies Substituted with Cassava (Mannihot utilissima) Leaf Flour}

\author{
Zainal $^{\left.1^{*}\right)}$, Amran Laga ${ }^{1)}$, dan Rahmatiah ${ }^{1)}$ \\ ${ }^{1 *}$ Program studi Ilmu dan Teknologi Pangan Departemen Teknologi Pertanian Universitas Hasanuddin, \\ Makassar, Indonesia \\ *email Penulis Korespondensi: zainal_burhan@yahoo.com
}

\begin{abstract}
ABSTRAK
Daun singkong merupakan daun hijau yang murah dan dapat dijumpai dimana saja. Penelitian ini menggunakan daun singkong jenis semaian (semen) yang bertangkai merah muda keputihan dengan warna daun hijau muda dibuat menjadi tepung untuk dijadikan produk olahan makanan. Tujuan dari penelitian ini adalah menganalisis sifat fisik dan kandungan kimiawi brownies kukus dengan penambahan tepung daun singkong berdasarkan uji mineral (Ca, P, Fe), kadar air, kadar abu, kadar protein, kadar lemak, kadar karbohidrat dan kadar serat kasar, menganalisis tingkat penilaian panelis terhadap brownies kukus berdasarkan hasil uji organoleptik dan menentukan formulasi produk kue brownies yang baik dari perbandingan tepung terigu dan tepung daun singkong yang digunakan. Penelitian ini dirancang dengan menggunakan Rancangan Acak Lengkap (RAL) dengan tiga kali ulangan yaitu A0 (100\% Tepung terigu : 0 (kontrol)), A1 (85\% Tepung terigu : 15\% Tepung daun singkong), A2 (70\% Tepung terigu : 30\% Tepung daun singkong) dan A3 (55\% Tepung terigu : 45\% Tepung daun singkong). Parameter yang diamati adalah uji proksimat yang meliputi (kadar air, kadar abu, kadar protein, kadar lemak, kadar karbohidrat), uji mineral (Ca, P, Fe), kadar serat kasar, uji organoleptik. Hasil penelitian terbaik adalah perlakuan A3 yang memiliki kadar air 20,83\%, kadar abu 2,88\%, kadar protein 9,48\%, kadar lemak $23,68 \%$, kadar karbohidrat $42,13 \%$ dan kadar serat 1,12\%, kandungan mineral kalsium 12,56 $\mathrm{g} / \mathrm{kg}$, fosfor 2,06 g/kg, zat besi 61,06 ppm. Hasil penilaian panelis terhadap tingkat kesukaan terhadap brownies kukus adalah pada perlakuan 100\% : 0 (penggunaan tepung terigu 100\%) dengan nilai rata-rata tekstur 4,08 (suka), warna 4,1 (suka), rasa 4,04 (suka), dan aroma 4 (suka).
\end{abstract}

Kata Kunci : Brownies, Daun singkong, Tepung Daun Singkong.

\begin{abstract}
Cassava leaves are abundant green leaves and affordable. This research uses cassava leaves of sleedlings type with white, pink stalk with light green leaf colour made into flour to be processed food products. The purpose of this research was to analyze the physical properties and chemical content of brownies steamed by the addition of cassava leaf flour based on a mineral test ( $\mathrm{Ca}, \mathrm{P}, \mathrm{Fe})$, water content, ash content, protein content, fat content, carbohydrate and crude fibre content. A panellist assessment of brownies steamed based on organoleptic test results and determining the formulation of good brownies cake products from the ratio of wheat flour and cassava flour used. This research was designed using Completely Randomized Design (RAL) with three replications such as AO (100\% wheat flour: $O$ (control)), A1 (85\% wheat flour: $15 \%$ cassava flour), A2 (70\% wheat flour: $30 \%$ cassava
\end{abstract}


flour) and A3 (55\% wheat flour: $45 \%$ cassava flour). The parameters observed were proximate tests which included (water content, ash content, protein content, fat content, carbohydrate content), mineral tests $(\mathrm{Ca}, \mathrm{P}, \mathrm{Fe})$, crude fibrecontent, organoleptic test. The best treatment was A3 which has water content $20,83 \%$, ash content $2,88 \%$, protein content $9,48 \%$, fat content $23,68 \%$, carbohydrate $42,13 \%$ and fiber content $1,12 \%$, content mineral calcium $12.56 \mathrm{~g} / \mathrm{kg}$, phosphorus $2.06 \mathrm{~g} / \mathrm{kg}$, iron $61.06 \mathrm{ppm}$. The result of the panellist's assessment of the level of preference to steamed brownies was AO with the average value of organoleptic score is texture 4.08 (like), colour 4,1 (like), taste 4.04 (like), and flavour 4 (like)

\section{Keywords : Brownies, Cassava (Mannihot utilissima) Cassava Leaves Flour}

\section{PENDAHULUAN}

Indonesia merupakan daerah tropis yang kaya akan sumber daya alam. Salah satu hasilnya adalah umbi-umbian seperti singkong. Singkong mempunyai potensi besar untuk dikembangkan sebagai produk olahan makanan, seperti yang kita ketahui singkong merupakan salah satu sumber kalori pangan yang paling murah di dunia.

Tanaman singkong umumnya daun singkong hanya diolah sebagai sayuran saja kini daunnya dapat dijadikan tepung untuk dibuat kue, seperti kue basah, dengan dibuatnya tepung daun singkong, maka makanan olahan dari bahan tepung semakin beragam. Jenis daun singkong yang digunakan dalam penelitian ini adalah jenis daun singkong semaian (semen) yang bertangkai merah muda keputihan dengan warna daun hijau muda. Daun singkong muda dipetik sebanyak lima tangkai dari bagian pucuk batang.

Brownies merupakan salah satu produk yang dibuat dari tepung-tepungan, selain itu, brownies juga merupakan makanan jajanan yang disukai anak-anak. Produk kue brownies saat ini sudah banyak variasi rasanya seperti rasa keju, pandan, durian dan ubi jalar. Makanan yang beranekaragam dapat diciptakan dengan memvariasikan penggunaan berbagai bahan pokok dengan berbagai teknologi pengolahan pangan. Penganekaragaman pangan juga berguna untuk mengurangi ketergantungan pada satu jenis pangan tertentu misalnya tepung terigu. Oleh karena itu, dengan adanya teknologi modifikasi diharapkan brownies tidak lagi sekedar makanan ringan saja, tetapi melalui penambahan tepung daun singkong dalam pembuatan brownies dapat meningkatkan kandungan gizi brownies, terlebih terhadap kandungan mineral seperti zat besi, kalsium dan fosfor.

Mengingat cukup tingginya nilai gizi dari daun singkong serta melimpahnya hasil produksi, maka pengenalan penggunaan tepung daun singkong kepada masyarakat akan lebih efektif bila diterapkan sebagai bahan baku atau bahan tambahan dalam pembuatan makanan yang sudah dikenal oleh masyarakat, salah satunya adalah brownies, dalam hal ini penambahan tepung daun singkong merupakan salah satu bentuk pengolahan makanan tambahan atau jajanan yang dimana dapat memberi tambahan zat gizi yang dibutuhkan. Berdasarkan hal tersebut peneliti mencoba memanfaatkan tepung daun singkong dalam pembuatan brownies kukus.

Kebutuhan penggunaan tepung terigu dalam pengolahan makanan semakin meningkat. Oleh karena itu, upaya untuk menekan kebutuhan penggunaan tepung terigu yaitu meningkatkan potensi komoditas yang ada. Bahan pangan lokal yang dapat dijadikan alternatif adalah daun singkong. Salah satu upaya pemanfaatan daun singkong adalah membuat tepung yang kemudian dijadikan produk makanan, seperti brownies. Namun, belum diketahui berapa banyak perbandingan tepung terigu dan tepung daun singkong untuk menghasilkan kue brownies yang baik dan dapat diterima panelis/konsumen. 
Tujuan yang ingin dicapai dari adalah untuk menganalisis sifat fisik dan kandungan kimiawi brownies dengan penambahan tepung daun singkong berdasarkan uji mineral $(\mathrm{Ca}, \mathrm{P}, \mathrm{Fe})$ dan uji proksimat yang meliputi kadar air, kadar abu, kadar protein, kadar lemak, kadar karbohidrat dan kadar serat kasar, menganalisis tingkat penilaian panelis terhadap brownies dengan penambahan tepung daun singkong berdasarkan hasil uji organoleptik, menentukan formulasi produk kue brownies yang baik dari perbandingan tepung terigu dan tepung daun singkong yang digunakan.

Kegunaan dari penelitian ini adalah sebagai bahan informasi dan acuan bagi masyarakat, industri pangan, maupun penelitian tentang cara pemanfaatan daun singkong dalam produk pangan, serta memberi alternatif varian produk brownies dengan kandungan gizi yang tinggi.

\section{METODOLOGI PENELITIAN}

\subsection{Alat}

Alat-alat yang digunakan dalam penelitian ini adalah baskom, sendok, ayakan tepung, timbangan analitik, grinder, oven, cetakan, panci, pengaduk, pisau.

\subsection{Bahan}

Bahan-bahan utama yang digunakan pada penelitian ini adalah tepung daun singkong, tepung terigu, gula pasir, telur, susu bubuk, vanili, margarin, baking powder, dark cokelat, cokelat batang, minyak sayur.

\subsection{Prosedur Penelitian}

\subsubsection{Pembuatan Tepung dan singkong}

Pembuatan tepung daun singkong dilakukan dengan menyiapkan daun singkong yang masih muda sebagai bahan baku. Selanjutnya direndam dalam air selama 6 (enam) jam dengan maksud untuk menghilangkan atau mengurangi senyawa sianida, daun singkong dibilas untuk menghilangkan kotoran. Kemudian diblansir uap selama 3 (tiga) menit, setelah itu, dikeringkan dalam oven pada suhu $60^{\circ} \mathrm{C}$ (Vakum drying), setelah daun singkong dikeringkan maka selanjutnya dilakukan penepungan dengan cara digiling menggunakan grinder. Selanjutnya diayak dengan ukuran ayakan 100 mesh

\subsubsection{Pembuatan Brownies}

Pembuatan brownies dilakukan dengan menyiapkan alat dan bahan. Langkah awal dimulai dengan menimbang gula pasir sebanyak $20 \%$ dan telur sebanyak $22 \%$ dikocok menggunakan mixer hingga mengembang. Kemudian ditambahkan susu skim sebanyak 3,2\%, vanili $0,4 \%$, dan baking powder $0,4 \%$. Selanjutnya ditambahkan dengan bahan pengisi yaitu tepung terigu dan tepung daun singkong berdasarkan perlakuan. Setelah itu, ditambahkan cokelat bubuk sebanyak 5\%, mixer hingga adonan tercampur merata. Masukkan cokelat batang $14 \%$ yang telah disteam dengan minyak sayur sebanyak $10 \%$, kocok hingga homogen. Selanjutnya masukkan adonan kedalam loyang yang telah diolesi margarin. Kemudian dilakukan pengukusan adonan selama \pm 30 menit dengan suhu $100^{\circ} \mathrm{C}$.

\subsection{Desain penelitian}

Penelitian ini dilakukan dengan perlakuan penambahan tepung terigu dan tepung daun singkong pada pembuatan brownies dengan perbandingan :

A0 $=100 \%$ Tepung terigu : 0 (kontrol)

$\mathrm{A} 1=85 \%$ Tepung terigu: $15 \%$ Tepung daun singkong

$\mathrm{A} 2=70 \%$ Tepung terigu: $30 \%$ Tepung daun singkong

$\mathrm{A} 3=55 \%$ Tepung terigu: $45 \%$ Tepung daun singkong

\subsection{Parameter pengamatan}

Parameter pengamatan pada penelitian ini yaitu uji organoleptik (rasa, warna, aroma, tekstur), uji kadar abu (AOAC, 1990), kadar air (Sudarmadji, Haryono, \& Suhardi, 1997), kadar lemak (Sudarmadji et 
al., 1997), kadar protein (Sudarmadji et al., 1997), kadar karbohidrat (Winarno, 2008) kadar serat kasar (Sudarmadji et al., 1997) dan uji mineral $(\mathrm{Ca}, \mathrm{P}, \mathrm{Fe})$ metode AAS (Atomic Absorption Spectroscopy) (Syahputra, 2004).

\section{HASIL DAN PEMBAHASAN}

\subsection{Analisa Tepung Daun Singkong}

Hasil analisa tepung daun singkong pada penelitian ini yaitu kadar air tepung daun singkong yang diperoleh adalah 5,6 \%. Analisa mineral yang diperoleh yaitu kalsium (Ca) $16 \mathrm{~g} / \mathrm{kg}$, fosfor (P) 3,9 g/kg, zat besi (Fe) 36,85 ppm, dan kadar serat tepung daun singkong yaitu $8,69 \%$.

\subsection{Analisa Produk Brownies Kukus}

\subsubsection{Kadar Air}

Penentuan kadar air terhadap brownies tersebut menggunakan metode berat kering (dry basis). Hasil analisa kadar air brownies kukus menunjukkan bahwa kadar air menurun dari $22,52 \%$ (penggunaan tepung terigu $100 \%$ ) ke 20,83\% (penggunaan tepung daun singkong $45 \%$

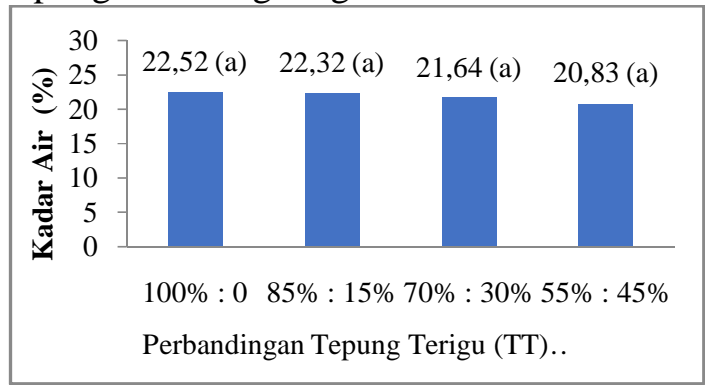

Gambar 1 Hubungan Antara Perbandingan Tepung Terigu Dengan Tepung Daun Singkong Terhadap Kadar Air Brownies Kukus

Hasil analisa sidik ragam menunjukkan bahwa pada setiap perlakuan tidak berpengaruh nyata pada taraf $5 \%$ terhadap kadar air brownies kukus yang dihasilkan. Hal ini disebabkan karena jumlah konsentrasi tepung daun singkong yang ditambahkan kecil. Selain itu, kadar air awal tepung daun singkong yang digunakan dalam pembuatan brownies kukus memiliki kadar air yang rendah yaitu sekitar 5,6\%. Kadar air yang rendah pada tepung daun singkong dipengaruhi oleh proses pengeringan dalam waktu yang lama. Semakin lama proses pengeringan, maka kadar air yang dihasilkan akan semakin rendah. Hal ini didukung oleh penelitian (Fitriani, 2008), yang menyatakan bahwa kemampuan bahan untuk melepaskan air dari permukaannya akan semakin besar dengan meningkatnya suhu udara pengering yang digunakan dan makin lamanya proses pengeringan, sehingga kadar air yang dihasilkan semakin rendah.

\subsubsection{Protein}

Hasil analisa kadar protein brownies kukus menunjukkan bahwa kadar protein meningkat dari 7,89\% (penggunaan tepung terigu $100 \%$ ) ke $9,48 \%$ (penggunaan tepung daun singkong 45\%). Berdasarkan hasil analisa sidik ragam menunjukkan adanya pengaruh nyata pada taraf $5 \%$ terhadap protein brownies kukus yang dihasilkan, sehingga dilakukan uji lanjut Duncan.

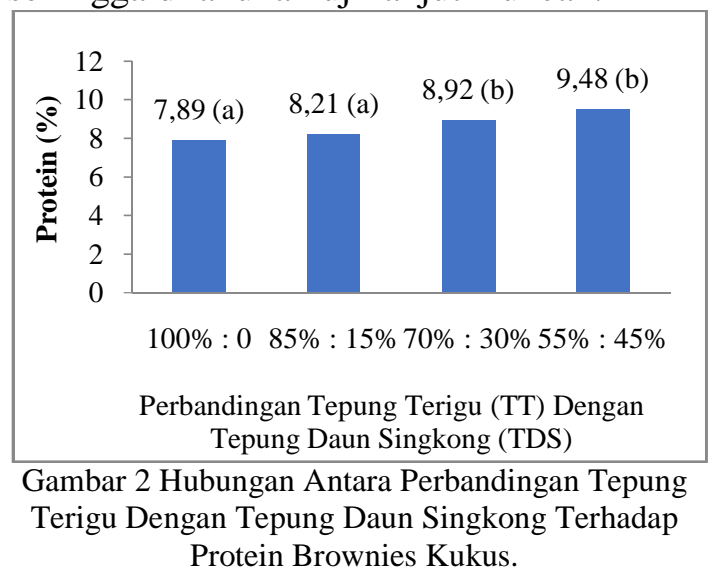

Hasil uji duncan menunjukkan bahwa perlakuan 100\% : 0 (penggunaan tepung terigu $100 \%$ ) tidak berbeda nyata dengan perlakuan $85 \%$ tepung terigu : $15 \%$ tepung daun singkong akan tetapi berbeda nyata dengan perlakuan $70 \%$ tepung terigu : $30 \%$ tepung daun singkong dan perlakuan $55 \%$ tepung terigu : $45 \%$ tepung daun singkong. Sedangkan perlakuan $55 \%$ tepung terigu : $45 \%$ tepung daun singkong tidak berbeda nyata dengan perlakuan $70 \%$ tepung terigu : $30 \%$ tetapi berbeda nyata dengan perlakuan $100 \%$ : 0 (penggunaan tepung terigu 100\%) dan perlakuan $85 \%$ tepung terigu : $15 \%$ 
tepung daun singkong. Hal ini disebabkan oleh pengaruh protein yang terdapat dalam tepung daun singkong tersebut yaitu sebesar $>20 \%$. Penambahan tepung daun singkong yang semakin meningkat akan menyebabkan kadar protein brownies kukus meningkat. Hal ini sesuai dengan (Marhaeniyanto, 2007), yang menyatakan bahwa daun singkong pada umumnya memiliki kandungan protein berkisar antara 20-27\% dari bahan kering. Dilihat dari tingginya kandungan protein kasar daun singkong sehingga dapat digunakan sebagai sumber protein alternatif.

\subsubsection{Kadar Abu}

Hasil analisa kadar abu terhadap brownies kukus menunjukkan bahwa kadar abu meningkat dari 1,8\% (penggunaan tepung terigu $100 \%$ ) ke $2,88 \%$ (penggunaan tepung daun singkong $45 \%$ ). Berdasarkan hasil analisa sidik ragam menunjukkan adanya pengaruh nyata pada taraf 5\% terhadap kadar abu brownies kukus yang dihasilkan, sehingga dilakukan uji lanjut duncan.

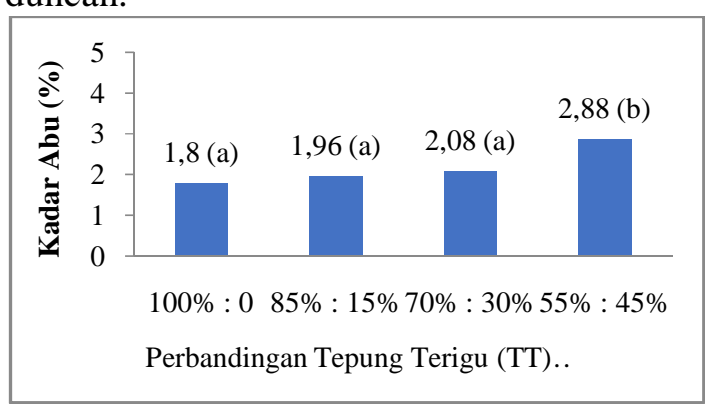

Gambar 3 Hubungan Antara Perbandingan Tepung Terigu Dengan Tepung Daun Singkong Terhadap Kadar Abu Brownies Kukus.

Hasil uji duncan menunjukkan bahwa perlakuan 100\% : 0 (penggunaan tepung terigu $100 \%$ ), perlakuan $85 \%$ tepung terigu : $15 \%$ tepung daun singkong dan perlakuan $70 \%$ tepung terigu : $30 \%$ tepung daun singkong tidak berbeda nyata tetapi berbeda nyata dengan perlakuan $55 \%$ tepung terigu : $45 \%$ tepung daun singkong. Hal ini dipengaruhi oleh penambahan tepung daun singkong yang telah melalui proses pengeringan. Semakin banyak penambahan tepung daun singkong yang pada brownies kukus, maka semakin meningkat pula kadar abu yang terkandung di dalamnya. Hal ini sesuai dengan (Susanto, 2011) yang menyatakan bahwa kadar abu pada suatu bahan semakin meningkat seiring dengan meningkatnya substitusi bahan tambahan.

\subsubsection{Kadar Lemak}

Hasil analisa kadar lemak terhadap brownies kukus menunjukkan bahwa kadar lemak meningkat dari 20,15\% (penggunaan tepung terigu $100 \%$ ) ke $23,68 \%$ (penggunaan tepung daun singkong 45\%)

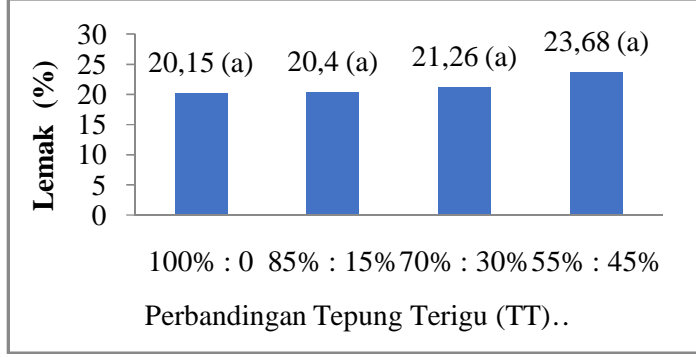

Gambar 4 Hubungan Antara Perbandingan Tepung Terigu Dengan Tepung Daun Singkong Terhadap Kadar Lemak Brownies Kukus.

Hasil analisa sidik ragam, menunjukkan bahwa pada setiap perlakuan tidak berpengaruh nyata pada taraf 5\% terhadap kadar lemak brownies kukus yang dihasilkan. Hal ini dipengaruhi kadar lemak pada tepung daun singkong yang rendah yaitu $\pm 12,9$ g per 100 gram tepung daun singkong, selain itu disebabkan oleh bahanbahan penyusunnya merupakan bahan yang mengandung lemak seperti telur, margarin dan coklat batang. Hal ini sesuai dengan (Sulistyo, 2006). yang menyatakan bahwa kandungan lemak yang terkandung didalam brownies sebagian besar berasal dari margarin, telur, coklat, dan susu bubuk skim.

\subsubsection{Karbohidrat}

Hasil analisa karbohidrat brownies kukus menunjukkan bahwa karbohidrat menurun dari $47,55 \%$ (penggunaan tepung terigu $100 \%$ ) ke $42,13 \%$ (penggunaan tepung daun singkong $45 \%$ ). Berdasarkan hasil yang diperoleh dapat disimpulkan bahwa jika persentasi penambahan tepung 
daun singkong makin besar maka kandungan karbohidrat yang dihasilkan semakin rendah. Hasil analisa sidik ragam menunjukkan adanya pengaruh nyata pada taraf 5\% terhadap kadar karbohidrat brownies kukus, sehingga dilakukan uji lanjut Duncan.

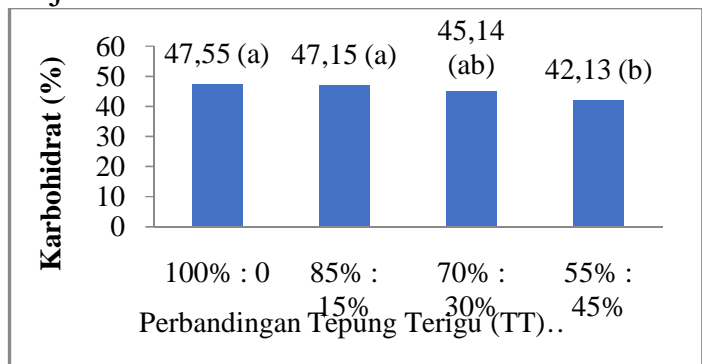

Gambar 5 Hubungan Antara Perbandingan Tepung Terigu Dengan Tepung Daun Singkong Terhadap Karbohidrat Brownies Kukus.

Hasil uji duncan menunjukkan bahwa perlakuan 100\% : 0 (penggunaan tepung terigu $100 \%$ ) tidak berbeda nyata dengan perlakuan $85 \%$ tepung terigu : $15 \%$ tepung daun singkong dan perlakuan $70 \%$ tepung terigu : $30 \%$ tepung daun singkong, akan tetapi berbeda nyata dengan perlakuan $55 \%$ tepung terigu : $45 \%$ tepung daun singkong. Sedangkan perlakuan 55\% tepung terigu : $45 \%$ tepung daun singkong tidak berbeda nyata dengan perlakuan $70 \%$ tepung terigu : $30 \%$ tepung daun singkong tetapi berbeda nyata dengan perlakuan $100 \%: 0$ (penggunaan tepung terigu $100 \%$ ) dan perlakuan $85 \%$ tepung terigu : $15 \%$ tepung daun singkong. Hal ini disebabkan karena kadar karbohidrat pada tepung daun singkong lebih rendah dibandingkan dengan tepung terigu. Pada tepung daun singkong per 100 gram kandungan karbohidratnya mencapai 13 gram, sedangkan pada tepung terigu kandungan karbohidratnya sebesar 70 gram. Tingginya kandungan karbohidrat pada tepung terigu ini karena karbohidrat merupakan komponen penyusun terbesar pada tepung terigu. Hal ini sesuai dengan (Astawan, 2009), yang menyatakan bahwa komponen terbesar dalam 100 gram tepung terigu adalah karbohidrat sebesar 70 gram.

\subsection{Kadar Serat Kasar}

Hasil analisa kadar serat kasar terhadap brownies kukus menunjukkan bahwa kadar serat meningkat dari $0,25 \%$ (penggunaan tepung terigu $100 \%$ ) ke $1,12 \%$ (penggunaan tepung daun singkong $45 \%$ ). Berdasarkan hasil analisa sidik ragam menunjukkan adanya pengaruh nyata pada taraf 5\% terhadap kadar serat brownies kukus yang dihasilkan, sehingga dilakukan uji lanjut duncan.

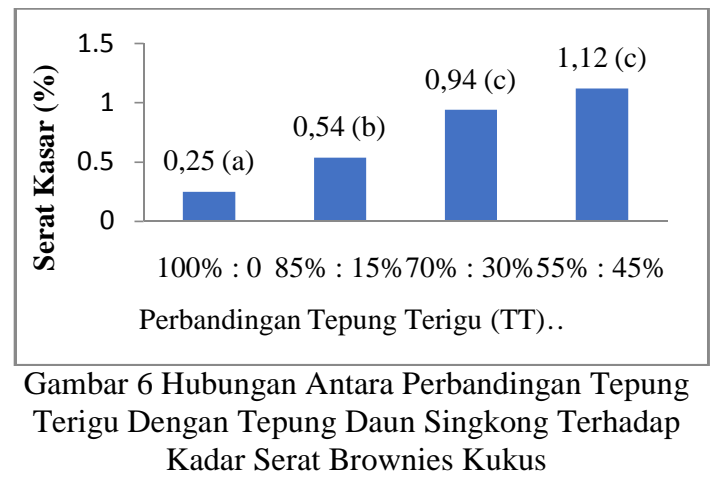

Hasil uji duncan menunjukkan bahwa perlakuan 100\% : 0 (penggunaan tepung terigu $100 \%$ ) berbeda nyata pada setiap perlakuan tetapi perlakuan $70 \%$ tepung terigu : $30 \%$ tepung daun singkong tidak berbeda nyata dengan perlakuan $55 \%$ tepung terigu : $45 \%$ tepung daun singkong. Hal ini dikarenakan penambahan tepung daun singkong, semakin banyak penambahan tepung daun singkong yang ditambahkan pada brownies kukus, maka semakin meningkat pula kadar serat yang terkandung di dalamnya. Hal ini sesuai dengan (Ardiyanti, 2001), yang menyatakan bahwa peningkatan kadar serat kasar terjadi karena pada kadar serat daun singkong mempunyai nilai cukup tinggi sebesar 15,12 gram dalam 100 gram tepung daun singkong, sehingga semakin besar substitusi tepung daun singkong yang ditambahkan maka kadar serat kasar brownies akan meningkat.

\subsection{Analisa Mineral}

\subsection{1 kadar Mineral Kalsium (Ca)}

Hasil analisa kadar kalsium terhadap brownies kukus menunjukkan bahwa kadar kalsium meningkat dari $6,46 \mathrm{~g} / \mathrm{kg}$ 
(penggunaan tepung terigu 100\%) ke 12,56 $\mathrm{g} / \mathrm{kg}$ (penggunaan tepung daun singkong $45 \%$ ). Berdasarkan hasil analisa sidik ragam menunjukkan adanya pengaruh nyata pada taraf 5\% terhadap kadar kalsium brownies kukus, sehingga dilakukan uji lanjut Duncan.

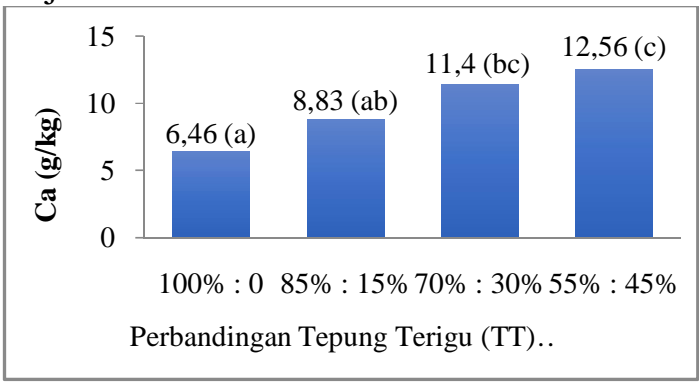

Gambar 7 Hubungan Antara Perbandingan Tepung Terigu Dengan Tepung Daun Singkong Terhadap

Kadar Mineral Kalsium Brownies Kukus.

Hasil uji duncan menunjukkan bahwa perlakuan 100\% : 0 (penggunaan tepung terigu $100 \%$ ) tidak berbeda nyata dengan perlakuan $85 \%$ tepung terigu : $15 \%$ tepung daun singkong tapi berbeda nyata pada perlakuan $70 \%$ tepung terigu : $30 \%$ tepung daun singkong dan perlakuan $55 \%$ tepung terigu : $45 \%$ tepung daun singkong. Perlakuan $85 \%$ tepung terigu : $15 \%$ tepung daun singkong tidak berbeda nyata dengan perlakuan 100\% : 0 (penggunaan tepung terigu $100 \%$ ) dan perlakuan $70 \%$ tepung terigu : $30 \%$ tepung daun singkong, tapi berbeda nyata dengan perlakuan $55 \%$ tepung terigu : $45 \%$ tepung daun singkong. Sedangkan perlakuan $55 \%$ tepung terigu : $45 \%$ tepung daun singkong tidak berbeda nyata dengan perlakuan $70 \%$ tepung terigu : $30 \%$ tepung daun singkong tapi berbeda nyata dengan perlakuan $100 \%$ : 0 (penggunaan tepung terigu $100 \%$ ) dan perlakuan $85 \%$ tepung terigu : $15 \%$ tepung daun singkong. Hal ini dipengaruhi oleh penambahan tepung daun singkong yang semakin meningkat akan menyebabkan kadar kalsium brownies kukus meningkat. Adonan brownies juga mengandung bahan tambahan seperti susu bubuk, dan telur. Bahan-bahan tambahan tersebut mengandung kalsium yang cukup tinggi, sehingga semakin banyak penambahannya maka akan menyebabkan akumulasi kadar kalsium meningkat. Hal ini sesuai dengan (Hidayat, 2006) yang menyatakan bahwa Sumber kalsium terutama pada susu dan hasilnya seperti keju, kacang-kacangan dan hasil olahannya, serta daun singkong.

\subsubsection{Kadar Mineral Fosfor (P)}

Hasil analisa kadar fosfor terhadap brownies kukus menunjukkan bahwa kadar fosfor meningkat dari 1,66 $\mathrm{g} / \mathrm{kg}$ (penggunaan tepung terigu 100\%) ke 2,06 $\mathrm{g} / \mathrm{kg}$ (penggunaan tepung daun singkong 45\%). Berdasarkan hasil analisa sidik ragam menunjukkan adanya pengaruh nyata pada taraf 5\% terhadap kadar fosfor brownies kukus, sehingga dilakukan uji lanjut Duncan

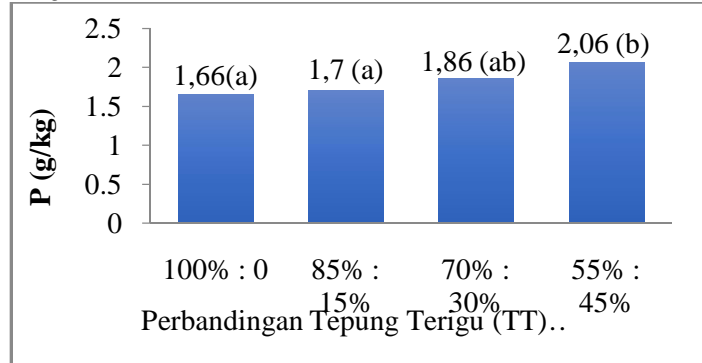

Gambar 8 Hubungan Antara Perbandingan Tepung Terigu Dengan Tepung Daun Singkong Terhadap Kadar Mineral Fosfor Brownies Kukus.

Hasil uji duncan menunjukkan bahwa perlakuan 100\% : 0 (penggunaan tepung terigu 100\%) tidak berbeda nyata pada perlakuan $85 \%$ tepung terigu : $15 \%$ tepung daun singkong dan perlakuan $70 \%$ tepung terigu : $30 \%$ tepung daun singkong tapi berbeda nyata pada perlakuan $55 \%$ tepung terigu : $45 \%$ tepung daun singkong. Perlakuan 55\% tepung terigu : $45 \%$ tepung daun singkong tidak berbeda nyata dengan perlakuan $70 \%$ tepung terigu : $30 \%$ tepung daun singkong, tapi berbeda nyata dengan perlakuan 100\% : 0 (penggunaan tepung terigu $100 \%$ ) dan perlakuan $85 \%$ tepung terigu : $15 \%$ tepung daun singkong. Hal ini karenakan pengaruh penambahan tepung daun singkong yang semakin meningkat akan menyebabkan kadar fosfor brownies kukus meningkat. Hal ini sesuai dengan (Hidayat, 2006), yang menyatakan bahwa sumber fosfor dan kalsium terutama pada susu dan hasilnya seperti keju, kacang- 
kacangan dan hasil olahannya, serta daun singkong.

\subsubsection{Kadar Mineral Besi (Fe)}

Hasil analisa kadar zat besi terhadap brownies kukus menunjukkan bahwa kadar zat besi meningkat dari 48,23 ppm (penggunaan tepung terigu 100\%) ke 61,06 ppm (penggunaan tepung daun singkong 45\%). Berdasarkan hasil analisa sidik ragam menunjukkan adanya pengaruh nyata pada taraf 5\% terhadap kadar zat besi brownies kukus, sehingga dilakukan uji lanjut Duncan.

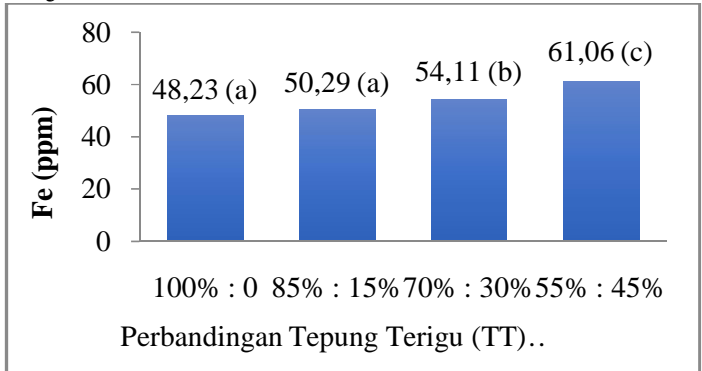

Gambar 9 Hubungan Antara Perbandingan Tepung Terigu Dengan Tepung Daun Singkong Terhadap Kadar Mineral Besi Brownies Kukus.

Hasil uji duncan menunjukkan bahwa perlakuan 100\% : 0 (penggunaan tepung terigu $100 \%$ ) tidak berbeda nyata pada perlakuan $85 \%$ tepung terigu : $15 \%$ tepung daun singkong tapi berbeda nyata pada perlakuan $70 \%$ tepung terigu : $30 \%$ tepung daun singkong dan perlakuan $55 \%$ tepung terigu : $45 \%$ tepung daun singkong. Perlakuan $70 \%$ tepung terigu : $30 \%$ tepung daun singkong berbeda nyata dengan perlakuan 100\% : 0 (penggunaan tepung terigu $100 \%$ ), perlakuan $85 \%$ tepung terigu : $15 \%$ tepung daun singkong dan perlakuan $55 \%$ tepung terigu : $45 \%$ tepung daun singkong. Begitu pun perlakuan 55\% tepung terigu : $45 \%$ tepung daun singkong berbeda nyata dengan perlakuan $100 \%$ : 0 (penggunaan tepung terigu 100\%), perlakuan $85 \%$ tepung terigu : $15 \%$ tepung daun singkong dan perlakuan $70 \%$ tepung terigu : $30 \%$ tepung daun singkong. Hal ini disebabkan karena pengaruh penambahan tepung daun singkong yang semakin meningkat akan menyebabkan kadar zat besi brownies kukus meningkat. Selain itu, pengaruh pengolahan dengan pengukusan merupakan metode pengolahan terbaik. Hal ini sesuai dengan (Hidayat, 2006), yang menyatakan bahwa sumber zat besi salah satunya berasal dari daun singkong. Hal ini didukung oleh (Musaiger \& D'Souza, 2008), yang menyatakan bahwa proses pengukusan adalah metode pengolahan dengan uap panas dimana bahan pangan tidak bersentuhan langsung dengan air melainkan dengan uap air, sehingga menghasilkan zat mineral larut air tidak berkurang secara berlebih.

\subsection{Uji Organoleptik produk brownies Kukus}

\subsubsection{Tekstur}

Hasil uji organoleptik parameter tekstur pada perbandingan tepung terigu dan tepung daun singkong terhadap brownies kukus yaitu pada perlakuan 100\%: 0 (penggunaan tepung terigu 100\%) yakni 4,08 (suka), perlakuan $85 \%$ tepung terigu : $15 \%$ tepung daun singkong yaitu 3,72 (agak suka), perlakuan $70 \%$ tepung terigu : $30 \%$ tepung daun singkong yaitu 3,4 (agak suka) dan perlakuan 55\% tepung terigu : $45 \%$ tepung daun singkong yaitu 3,28 (agak suka). Berdasarkan hasil yang diperoleh dapat disimpulkan bahwa semakin tinggi penambahan tepung daun singkong maka tekstur dari produk brownies kukus semakin tidak disukai. Hasil analisa sidik ragam menunjukkan bahwa adanya pengaruh nyata pada taraf 5\% terhadap parameter tekstur brownies kukus, sehingga dilakukan uji lanjut Duncan.

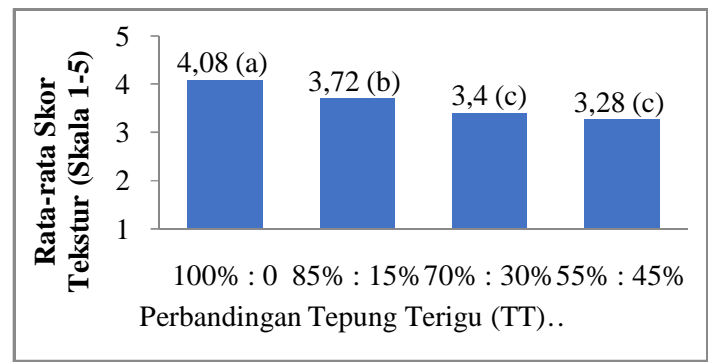

Gambar 10 Hubungan Antara Perbandingan Tepung Terigu Dengan Tepung Daun Singkong Terhadap Tekstur Brownies Kukus. 
Hasil uji duncan menunjukkan bahwa tekstur pada brownies kukus perlakuan 100\% : 0 (penggunaan tepung terigu 100\%) berbeda nyata dengan perlakuan $85 \%$ tepung terigu : $15 \%$ tepung daun singkong, perlakuan $70 \%$ tepung terigu : $30 \%$ tepung daun singkong, dan perlakuan 55\% tepung terigu : $45 \%$ tepung daun singkong. Begitupun dengan perlakuan $85 \%$ tepung terigu : $15 \%$ tepung daun singkong berbeda nyata dengan perlakuan $100 \%: 0$ (penggunaan tepung terigu 100\%), 70\% tepung terigu : $30 \%$ tepung daun singkong, dan perlakuan $55 \%$ tepung terigu : $45 \%$ tepung daun singkong. Sedangkan $70 \%$ tepung terigu : $30 \%$ tepung daun singkong tidak berbeda nyata dengan perlakuan $55 \%$ tepung terigu : $45 \%$ tepung daun singkong tapi berbeda nyata dengan perlakuan 100\% : 0 (penggunaan tepung terigu 100\%) dan perlakuan $85 \%$ tepung terigu : $15 \%$ tepung daun singkong. Tekstur brownies kukus yang padat terbentuk karena adanya penambahan tepung daun singkong, dimana pada tepung daun singkong memiliki kandungan serat yang tinggi. Hal ini juga disebabkan karena adanya penambahan gula dan telur. Hal ini sesuai dengan (Mats \& Matz, 1978) yang menyatakan bahwa telur mempengaruhi tekstur karena memiliki sifat pengemulsi, pelembut, dan pengikat. semakin tinggi jumlah gula yang ditambahkan dalam adonan maka semakin keras pula produk yang dihasilkan.

\subsubsection{Warna}

Hasil uji organoleptik parameter warna pada perbandingan tepung terigu dan tepung daun singkong terhadap brownies kukus yaitu pada perlakuan 100\% : 0 (penggunaan tepung terigu $100 \%$ ) yakni 4,1 (suka), perlakuan $85 \%$ tepung terigu : $15 \%$ tepung daun singkong yaitu 4,05 (suka), perlakuan $70 \%$ tepung terigu : $30 \%$ tepung daun singkong yaitu 4,02 (suka) dan perlakuan 55\% tepung terigu : $45 \%$ tepung daun singkong yaitu 4,02 (suka).

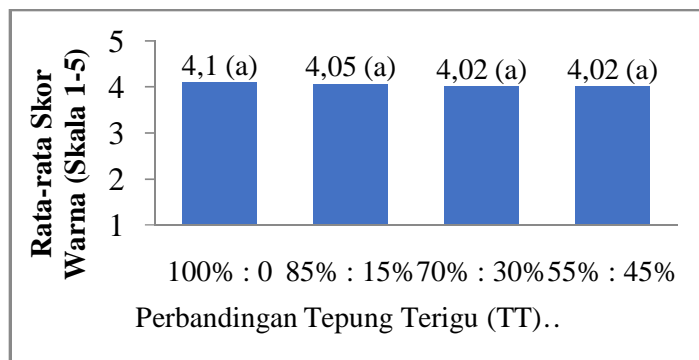

Gambar 11 Hubungan Antara Perbandingan Tepung Terigu Dengan Tepung Daun Singkong Terhadap Warna Brownies Kukus.

Berdasarkan hasil analisa sidik ragam menunjukkan bahwa tidak terdapat pengaruh nyata pada taraf $5 \%$ terhadap parameter warna brownies kukus. Warna brownies kukus yang gelap terbentuk karena pada daun singkong mengandung pigmen klorofil berwarna hijau. Hal ini sesuai dengan (Winarno, 1997), yang menyatakan bahwa penyebab suatu bahan makanan berwarna adalah salah satunya karena adanya pigmen yang dikandung oleh bahan makanan tersebut. Warna pigmen klorofil umumnya hijau atau coklat, dan biasanya dijumpai pada sayuran dan buahbuahan. Klorofil dalam daun yang masih hidup berikatan dengan protein, dalam proses pemanasan proteinnya terdenaturasi dan klorofil dilepaskan.

\subsubsection{Rasa}

Hasil uji organoleptik parameter rasa pada perbandingan tepung terigu dan tepung daun singkong terhadap brownies kukus yaitu pada perlakuan 100\% : 0 (penggunaan tepung terigu 100\%) yakni 4,04 (suka), perlakuan $85 \%$ tepung terigu : $15 \%$ tepung daun singkong yaitu 3,12 (agak suka), $70 \%$ tepung terigu : $30 \%$ tepung daun singkong yaitu 2,72 (tidak suka), 55\% tepung terigu : $45 \%$ tepung daun singkong yaitu 2,6 (tidak suka). Berdasarkan hasil yang diperoleh dapat disimpulkan bahwa semakin tinggi penambahan tepung daun singkong maka rasa pada brownies kukus yang dihasilkan akan semakin sepat dan tidak disukai panelis. 


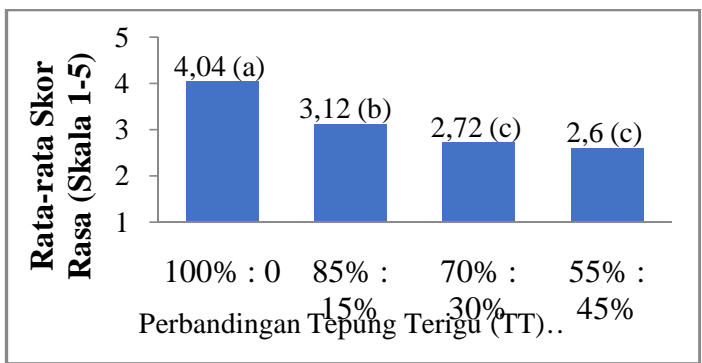

Gambar 12 Hubungan Antara Perbandingan Tepung Terigu Dengan Tepung Daun Singkong Terhadap Rasa Brownies Kukus

Hasil analisa sidik ragam menunjukkan bahwa terdapat pengaruh nyata pada taraf 5\% terhadap parameter rasa brownies kukus, sehingga dilakukan uji lanjut duncan. Hasil uji duncan menunjukkan bahwa tekstur pada brownies kukus perlakuan 100\% : 0 (penggunaan tepung terigu $100 \%$ ) berbeda nyata dengan perlakuan $85 \%$ tepung terigu : $15 \%$ tepung daun singkong, perlakuan $70 \%$ tepung terigu : $30 \%$ tepung daun singkong, dan perlakuan $55 \%$ tepung terigu : $45 \%$ tepung daun singkong. Begitupun dengan perlakuan $85 \%$ tepung terigu : $15 \%$ tepung daun singkong berbeda nyata dengan perlakuan 100\% : 0 (penggunaan tepung terigu $100 \%$ ), $70 \%$ tepung terigu : $30 \%$ tepung daun singkong, dan perlakuan $55 \%$ tepung terigu : $45 \%$ tepung daun singkong. Sedangkan $70 \%$ tepung terigu : $30 \%$ tepung daun singkong tidak berbeda nyata dengan perlakuan 55\% tepung terigu : $45 \%$ tepung daun singkong tapi berbeda nyata dengan perlakuan 100\% : 0 (penggunaan tepung terigu $100 \%$ ) dan perlakuan $85 \%$ tepung terigu : $15 \%$ tepung daun singkong. Hal ini dipengaruhi oleh penambahan tepung daun singkong, dimana daun singkong memiliki rasa sepat, sehingga semakin tinggi konsentrasi penambahan tepung daun singkong pada pembuatan brownies kukus maka semakin tidak disukai oleh panelis. Penambahan tepung daun singkong dengan berbagai variasi memberi pengaruh yang berbeda nyata terhadap rasa brownies kukus yang dihasilkan Hal ini sesuai dengan (Winarno, 1997), yang menyatakan bahwa rasa suatu makanan merupakan faktor yang turut menentukan daya terima konsumen.
Rasa dipengaruhi oleh beberapa faktor yaitu senyawa kimia, suhu, konsentrasi dan interaksi dengan komponen rasa yang lain.

\subsubsection{Aroma}

Hasil uji organoleptik parameter aroma pada perbandingan tepung terigu dan tepung daun singkong terhadap brownies kukus yaitu pada perlakuan 100\% : 0 (penggunaan tepung terigu 100\%) yakni 4 (suka), perlakuan $85 \%$ tepung terigu : $15 \%$ tepung daun singkong yaitu 3,4 (agak suka), perlakuan $70 \%$ tepung terigu : $30 \%$ tepung daun singkong yaitu 3,36 (agak suka) dan perlakuan $55 \%$ tepung terigu : $45 \%$ tepung daun singkong yaitu 3,13 (agak suka). Hasil analisa sidik ragam menunjukkan bahwa terdapat pengaruh nyata pada taraf 5\% terhadap parameter aroma brownies kukus, sehingga dilakukan uji lanjut Duncan.

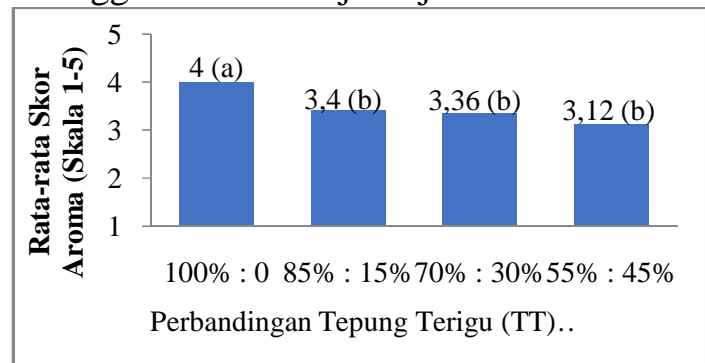

Gambar 13 Hubungan Antara Perbandingan Tepung Terigu Dengan Tepung Daun Singkong Terhadap Aroma Brownies.

Hasil uji lanjut duncan terhadap parameter aroma menunjukkan bahwa pada perlakuan 100\% : 0 (penggunaan tepung terigu 100\%) berbeda nyata dengan perlakuan $85 \%$ tepung terigu : $15 \%$ tepung daun singkong, perlakuan $70 \%$ tepung terigu : $30 \%$ tepung daun singkong dan perlakuan $55 \%$ tepung terigu : $45 \%$ tepung daun singkong. Begitupun dengan perlakuan $55 \%$ tepung terigu : $45 \%$ tepung daun singkong tidak berbeda nyata dengan perlakuan $70 \%$ tepung terigu : $30 \%$ tepung daun singkong dan perlakuan $85 \%$ tepung terigu : $15 \%$ tepung daun singkong, tetapi berbeda nyata dengan perlakuan 100\% : 0 (penggunaan tepung terigu $100 \%$ ). Hal ini dipengaruhi oleh penambahan tepung daun singkong yang memiliki aroma khas daun singkong, semakin tinggi konsentrasi penambahan 
tepung daun singkong pada pembuatan brownies kukus maka aroma yang dihasilkan semakin tinggi. Selain itu, perbedaaan pendapat setiap orang memiliki perbedaan penciuman, meskipun mereka dapat membedakan aroma namun setiap orang mempunyai kesukaan yang berlainan. Hal ini sesuai dengan (Winarno, 1997), penerimaan indera penciuman akan berkurang oleh adanya senyawa-senyawa tertentu seperti misalnya formaldehida. Kelelahan daya penciuman terhadap bau dapat terjadi dengan cepat.

\section{KESIMPULAN}

1. Hasil sifat fisik dan kandungan kimiawi brownies kukus yang terbaik adalah brownies pada perbandingan 55\% tepung terigu (TT) dengan $45 \%$ tepung daun singkong (TDS). Berdasarkan hasil analisa diperoleh kadar air 20,83\%, kadar abu 2,88\%, kadar protein 9,48\%, kadar lemak 23,68\%, kadar karbohidrat $42,13 \%$ dan kadar serat 1,12\%, kandungan mineral kalsium 12,56 g/kg, fosfor $2,06 \mathrm{~g} / \mathrm{kg}$, zat besi 61,06 ppm. Hal ini menunjukkan bahwa semakin tinggi penambahan tepung daun singkong maka kandungan gizi dari produk akan semakin tinggi pula.

2. Hasil penilaian panelis terbaik terhadap tingkat kesukaan brownies kukus adalah pada perlakuan 100\% : 0 (penggunaan tepung terigu $100 \%$ ) dengan nilai ratarata tekstur 4,08 (suka), warna 4,1 (suka), rasa 4,04 (suka), dan aroma 4 (suka). Hal ini menunjukkan bahwa tepung daun singkong memberikan pengaruh terhadap produk brownies kukus yang dihasilkan.

3. Perlakuan $55 \%$ tepung terigu (TT) dengan $45 \%$ tepung daun singkong (TDS) merupakan formulasi yang terbaik berdasarkan hasil pengujian proksimat.

\section{DAFTAR PUSTAKA}

AOAC. (1990). Official Methods of
Analysis of AOAC International. In Association of Official Analysis Chemists International. https://doi.org/10.3109/155636576089 88149

Ardiyanti. (2001). Pengaruh Proporsi Tepung Terigu dengan Bran Gandum Sebagai Sumber Serat dan Penambahan Margarin Terhadap Mutu Cookies. Universitas Brawijaya, Malang.

Astawan. (2009). A Z Ensiklopedia Gizi Pangan. Jakarta: Dian Rakyat.

Fitriani. (2008). Pengaruh Suhu dan Lama Pengeringan Terhadap Beberapa Mtu Manisan Belimbing Wuluh (Averrhoa bilimbi L) Kering. Jurnal Sagu, 7(1), 32-37.

Hidayat. (2006). Mikrobiologi Industri. Yogyakarta: Andi Offset.

Marhaeniyanto. (2007). Pemanfaatan Silase Daun Umbi Kayu untuk Pakan Ternak Kambaing. Buana Sains, 7(1), 71-82.

Mats, S. ., \& Matz, T. . (1978). Cookies and Crackers Technology. The AVI Publishing Co.

Musaiger, A. O., \& D'Souza, R. (2008). The effects of different methods of cooking on proximate, mineral and heavy metal composition of fish and shrimps consumed in the Arabian Gulf. Archivos Latinoamericanos de Nutricion.

Sudarmadji, Haryono, \& Suhardi. (1997). Prosedur Analisa Untuk Bahan Makanan dan Pertanian. Yogyakarta: Liberty Press.

Sulistyo. (2006). Kinetic Studies on the Reduction of Trace Cr (VI) in Natural Water by Flow Injection Solid Phase Spectrometry. Japan.

Susanto. (2011). Potensi Bekatul Sebagai Sumber Antioksidan dalam Produk Selai Kacang. Universitas Diponegoro,Semarang.

Syahputra. (2004). Modul Pelatihan Instrumentasi AAS. UII.

Winarno. (1997). Teknologi Produksi dan Kualitas Mi. Bogor.: IPB-Press.

Winarno. (2008). Kimia Pangan dan Gizi. 
Bogor.: bio:Press. 